\title{
Synthesis, Spectroscopic, Anticancer, and Antimicrobial Properties of Some Metal(II) Complexes of (Substituted) Nitrophenol Schiff Base
}

\author{
Aderoju A. Osowole, ${ }^{1}$ Ingo Ott, ${ }^{2}$ and Oladunni M. Ogunlana ${ }^{1}$ \\ ${ }^{1}$ Inorganic Chemistry Unit, Department of Chemistry, University of Ibadan, Ibadan, Nigeria \\ ${ }^{2}$ Institute of Medicinal and Pharmaceutical Chemistry, Technical University Braunchweig, \\ Beethoven Straße 55, 38106 Braunschweig, Germany
}

Correspondence should be addressed to Aderoju A. Osowole, aderoju30@yahoo.com

Received 6 November 2011; Accepted 2 January 2012

Academic Editor: Rabindranath Mukherjee

Copyright ( 2012 Aderoju A. Osowole et al. This is an open access article distributed under the Creative Commons Attribution License, which permits unrestricted use, distribution, and reproduction in any medium, provided the original work is properly cited.

\begin{abstract}
The Schiff base, 2-[(2,3-dihydro-1H-inden-4-ylimino)methyl]-5-nitrophenol coordinates to $\mathrm{Mn}(\mathrm{II}), \mathrm{Cu}(\mathrm{II}), \mathrm{Zn}(\mathrm{II})$, and $\mathrm{Pd}$ (II) ions through the phenolic $O$ and imine $N$ atoms. The complexes are characterized by physicochemical and spectroscopic methods. The metal complexes formed as $\left[\mathrm{ML}_{2}\right] x \mathrm{H}_{2} \mathrm{O}$ with exception of the $\mathrm{Cu}(\mathrm{II})$ complex which is anhydrous. Spectroscopic data corroborate the adoption of a four-coordinate, tetrahedral geometry for the $\mathrm{Mn}$ (II), and $\mathrm{Zn}$ (II) complexes, and a four-coordinate, square planar geometry for the $\mathrm{Cu}(\mathrm{II})$ and $\mathrm{Pd}(\mathrm{II})$ complexes. None is an electrolyte in DMSO. The in vitro anticancer activities of the metal free ligand, $\mathrm{Cu}$ (II), Zn(II), and Pd(II) complexes against MCF-7 (human breast adenocarcinoma) and HT-29 (colon carcinoma) cells reveal that the $\mathrm{Pd}(\mathrm{II})$ complex has the best cytotoxic activity against MCF-7 cells with an $\mathrm{IC}_{50}$ of $5.94 \mu \mathrm{M}$, which is within the same order of activity as cisplatin. Furthermore, the ligand and the $\mathrm{Zn}$ (II) complex exhibit broad-spectrum activity against two gram-positive bacteria, three gram-negative bacteria, and a fungus with inhibitory zones range of 10.0-20.0 and 10.0$17.0 \mathrm{~mm}$, respectively.
\end{abstract}

\section{Introduction}

Tridentate aminoindane Schiff base Cr(III) compounds have been used as catalysts in enantioselective inverseelectron-demand hetero-Diels-Alder reactions of $\alpha, \beta$-unsaturated aldehydes and ring opening of meso-aziridines $[1,2]$. Fur- thermore, some amino-1-indanols possess valuable bronchodilator properties, For example, 6-methoxy2-isopropylamino-1-indanol [3], while N-propargylamine$1(\mathrm{R})$-aminoindane exhibits antiapoptotic properties against dopaminergic SH-SY5Y cells. Additionally, Schiff bases derived from indane-1, 3-dione-2-imine- $\mathrm{N}$-acetic acid, 2imino-N-2-propionic acid and ninhydrin, glycine/L-alanine, and their metal(II) com-plexes exhibit unique geometries, and good antimicrobial activities against E. coli, $P$. mirabilis, S. aureus, and $P$. faecalis $[4,5]$, while those derived from 4-amino-1,3-dimethyl-2,6-pyridinedione and various hydroxy benzaldehyde are potent antimicrobials. Tricyclic pyrimidine and aminobenzene sulfonamido Schiff bases showed anti-HIV activity and high antitumor activity with low therapeutic index against murine S-180 carcinoma [6-8], and N-substituted-3-chloro-2-azetidinones Schiff bases have good anthelmintic activity against earthworms [9]. Extensive literature search shows that no work is reported on the Schiff base, 2-[(2,3-dihydro- $1 H$-inden-4ylimino)methyl]-5-nitrophenol (derived from condensation of 4-aminoindane and 2-hydroxy-5-nitrobenzaldehyde) and its $\mathrm{Mn}(\mathrm{II}), \mathrm{Cu}(\mathrm{II}), \mathrm{Zn}(\mathrm{II})$, and $\mathrm{Pd}(\mathrm{II})$ complexes [10-14]. Thus, our aim is to synthesize and characterize the above named Schiff base and its metal(II) complexes in order to investigate their antimicrobial and anticancer properties for further studies in drug development for infectious diseases and cancer. The choice of $\mathrm{Cu}(\mathrm{II})$ and $\mathrm{Zn}(\mathrm{II})$ for cytotoxic studies is based on their importance in humans as 
antioxidant, growth, and fertility promoter [15], while Pd, a rare metal with no known biological function is chosen for its renowned antitumor activity [16]. The ligand used in this study, HL and its metal(II) complexes are new and are being reported for the first time by us as a continuation of our studies on the synthesis, characterization, and bioactivities of some metal(II) complexes of various Schiff bases [17-20].

\section{Experimental}

Reagent grade 4-aminoindane, 2-hyroxy-5-nitrobenzaldehyde, hydrated manganese(II) nitrate, copper(II) nitrate, zinc(II) nitrate, and palladium(II) chloride were purchased from Aldrich and BDH chemicals and were used as received. Solvents were purified by distillation.

The microbes, Bacillus subtilis ATTC 33932, Salmonella thyphi, Proteus mirabilis ATTC 21784, Candida albicans MTTC 227, Pseudomonas aeruginosa ATTC 27856, and Bacillus cereus ATTC 14579, were obtained from the Organic Chemistry Unit, Department of Chemistry, University of Ibadan, Ibadan, Nigeria, while MCF-7 (human breast adenocarcinoma) and HT-29 (colon carcinoma) cells were cultured at the Institute of Medicinal and Pharmaceutical Chemistry, Technical University Braunschweig, Germany.

The elemental analyses for $\mathrm{C}, \mathrm{H}$, and $\mathrm{N}$ were recorded on Thermo Quest CE Instruments flash EA1112 analyser. Manganese, copper, zinc and palladium were determined titrimetrically [21]. The ${ }^{1} \mathrm{H}$ NMR spectra were recorded on a $300 \mathrm{MHz}$ Brucker DRX-400 NMR instrument in $\mathrm{CD}_{2} \mathrm{Cl}_{2}$ at $295 \mathrm{~K} .{ }^{1} \mathrm{H}$ chemical shifts were referenced to the residual signals of the protons of $\mathrm{CD}_{2} \mathrm{Cl}_{2}$ and were quoted in ppm. The reflectance and infrared spectra ( $\mathrm{KBr}$ discs) were recorded on a Perkin-Elmer $\lambda 25$ spectrophotometer and Perkin-Elmer FTIR spectrum BX spectrophotometer in the range $900-190 \mathrm{~nm}$ and $4000-400 \mathrm{~cm}^{-1}$, respectively. Electrolytic conductivities of the compounds in DMSO were determined using a MC-1, Mark V conductivity meter with a cell constant of 1.0 and melting points (uncorrected) were done with a Mel-Temp electrothermal machine.

2.1. Preparation of 2-[(2,3-Dihydro-1H-inden-4-ylimino)methyl]-5-nitrophenol. The ligand, HL, was prepared by stirring and heating a $50 \mathrm{~mL}$ ethanolic solution of $7.5 \mathrm{mmol}(1.0 \mathrm{~g})$ of 4 -amino indane to which $7.5 \mathrm{mmol}$ (1.26 g) of 2-hydroxy5 -nitrobenzaldehyde was added neat and in bits at $70^{\circ} \mathrm{C}$. The resulting homogeneous dark brown solution was then refluxed for $3 \mathrm{~h}$ after addition of 4 drops of acetic acid. The orange product, formed on cooling in ice, was filtered and recrystallized from ethanol and dried in vacuo over anhydrous calcium chloride. The yield of HL was $1.48 \mathrm{~g}$ (70\%).

Color (orange); IR $\left(\mathrm{KBr}, \mathrm{cm}^{-1}\right): \nu \mathrm{OH}(3427 \mathrm{~s}), \nu \mathrm{C}=\mathrm{N}+$ $\nu \mathrm{C}=\mathrm{C}(1650 \mathrm{~s} 1421 \mathrm{~s}) ; \mathrm{UV} \lambda_{\max }(\mathrm{kK}): 28.72,36.46,42.73 ;{ }^{1} \mathrm{H}$ $\operatorname{NMR}\left(300 \mathrm{MHz}, \mathrm{CD}_{2} \mathrm{Cl}_{2}, \delta\right.$ in ppm): $15.0\left(\mathrm{~s}, 1 \mathrm{H}, \mathrm{C}^{2} \mathrm{OH}\right)$, $8.78\left(\mathrm{~s}, 1 \mathrm{H}, \mathrm{HC}^{7} \mathrm{~N}\right), 8.42-8.22\left(\mathrm{~m}, 3 \mathrm{H}, \mathrm{C}^{3}, \mathrm{C}^{4}, \mathrm{C}^{6}\right)$, Indane ring: 7.29-7.06 (m, 3H, $\left.\mathrm{C}^{5^{\prime}}, \mathrm{C}^{6^{\prime}}, \mathrm{C}^{7^{\prime}}\right) ; 3.02\left(\mathrm{t}, 2 \mathrm{H}, \mathrm{C}^{\mathrm{l}^{\prime}}\right), 2.15$ $\left(\mathrm{q}, 2 \mathrm{H}, \mathrm{C}^{2^{\prime}}\right), 3.05\left(\mathrm{t}, 2 \mathrm{H}, \mathrm{C}^{3^{\prime}}\right)$; M.pt $\left({ }^{\circ} \mathrm{C}\right), 152-153$; formula mass (282.29); $\mathrm{CHN}$ Anal. calcd(found) for $\mathrm{C}_{16} \mathrm{H}_{14} \mathrm{~N}_{2} \mathrm{O}_{3}$ : C, 68.1 (68.4); H, 5.0 (4.8); N, 9.9 (9.5).
2.2. Preparation of the Metal(II) Complexes. The various complexes were prepared by refluxing a homogeneous solution of $0.30 \mathrm{mmol}(0.053-0.089 \mathrm{~g})$ of hydrated M(II) nitrates $(\mathrm{M}=\mathrm{Mn}, \mathrm{Cu}, \mathrm{Zn})$ and $0.60 \mathrm{mmol}(0.17 \mathrm{~g})$ of the ligand, to which $0.06 \mathrm{mmol}(0.061 \mathrm{~g})$ of triethylamine was added in $30 \mathrm{~mL}$ ethanol for $3 \mathrm{~h}$. The products formed were filtered, washed with ethanol, and dried in vacuo over anhydrous calcium chloride. The same procedure was used to prepare the $\mathrm{Pd}(\mathrm{II})$ complexes from its chloride salt, respectively. The analytical data were as follows.

$\left[\mathrm{MnL}_{2}\right] 2 \mathrm{H}_{2} \mathrm{O}$ : \% yield 70 (0.14 g); Color (brown); IR $\left(\mathrm{KBr}, \mathrm{cm}^{-1}\right): \nu \mathrm{OH}(3500 \mathrm{~b}), \nu \mathrm{C}=\mathrm{N}+\nu \mathrm{C}=\mathrm{C}(1637 \mathrm{~s} 1404 \mathrm{~s})$, $\nu \mathrm{M}-\mathrm{N}(524 \mathrm{~m} 502 \mathrm{~m}), v \mathrm{M}-\mathrm{O}(458 \mathrm{~m} 430 \mathrm{~m})$; VIS/UV $\lambda_{\max }$, $(\mathrm{kK})$ : 12.0, 22.10, 31.8, 39.2, 42.8; M.pt $\left({ }^{\circ} \mathrm{C}\right), 171-173$; formula mass (653.54); CHN Anal. calcd(found) for $\mathrm{Mn}$ $\left(\mathrm{C}_{32} \mathrm{H}_{30} \mathrm{~N}_{4} \mathrm{O}_{8}\right)$ C, 58.8 (58.5); H, 4.6 (4.4); N, 8.5 (8.2); \%Mn calcd(found) $8.4(8.4) ; \Lambda_{\mathrm{m}}, 1.05$.

$\left[\mathrm{CuL}_{2}\right]$ : \% yield $70(0.13 \mathrm{~g})$; Color (green); IR (KBr, $\left.\mathrm{cm}^{-1}\right): \nu \mathrm{C}=\mathrm{N}+\nu \mathrm{C}=\mathrm{C}(1660 \mathrm{~s} 1420 \mathrm{~s}), \nu \mathrm{M}-\mathrm{N}(572 \mathrm{~m} 512 \mathrm{~m})$, $v \mathrm{M}-\mathrm{O}(481 \mathrm{~m} 429 \mathrm{~m})$; VIS/UV $\lambda_{\max }(\mathrm{kK}): 13.89,22.52$, 31.71, 41.70; M.pt ( $\left.{ }^{\circ} \mathrm{C}\right), 288-290$; formula mass (626.11); CHN Anal. calcd(found) for $\mathrm{Cu}\left(\mathrm{C}_{32} \mathrm{H}_{26} \mathrm{~N}_{4} \mathrm{O}_{6}\right) \mathrm{C}, 61.4(61.2)$; H, 4.2 (4.2); N, 9.0 (8.3); \%Cu calcd(found) 10.2 (10.1); $\Lambda_{\mathrm{m}}$, 30.0 .

$\left[\mathrm{ZnL}_{2}\right] \mathrm{H}_{2} \mathrm{O}$ : \% yield 70 (0.14 g); Color (yellow); IR (KBr, $\left.\mathrm{cm}^{-1}\right): \nu \mathrm{OH} 3500 \mathrm{~b}, \nu \mathrm{C}=\mathrm{N}+\nu \mathrm{C}=\mathrm{C}, 1675 \mathrm{~s} 1440 \mathrm{~s} ; \nu \mathrm{M}-\mathrm{N}$ $580 \mathrm{~m} 518 \mathrm{~m}, v \mathrm{M}-\mathrm{O} 470 \mathrm{~m} 410 \mathrm{~m}$; VIS/UV $\lambda_{\max },(\mathrm{kK}): 21.50$, 33.60, 42.0; ${ }^{1} \mathrm{H}$ NMR (300 MHz, $\mathrm{CD}_{2} \mathrm{Cl}_{2}, \delta$ in ppm): 8.76 $\left(\mathrm{s}, 1 \mathrm{H}, \mathrm{HC}^{7^{\prime}} \mathrm{N}\right), 8.19-8.41\left(\mathrm{~m}, 3 \mathrm{H}, \mathrm{C}^{3^{\prime}}, \mathrm{C}^{4^{\prime}}, \mathrm{C}^{6^{\prime}}\right)$, Indane ring: 7.0-7.14 (m, 3H, $\left.\mathrm{C}^{2}, \mathrm{C}^{3}, \mathrm{C}^{4}\right) ; 3.0\left(\mathrm{t}, 2 \mathrm{H}, \mathrm{C}^{5}\right), 2.16(\mathrm{q}$, $\left.2 \mathrm{H}, \mathrm{C}^{6}\right), 3.06\left(\mathrm{t}, 2 \mathrm{H}, \mathrm{C}^{7}\right)$; M.pt $\left({ }^{\circ} \mathrm{C}\right), 262-264$; formula mass (645.95); CHN Anal. calcd(found) for $\mathrm{Zn}\left(\mathrm{C}_{32} \mathrm{H}_{28} \mathrm{~N}_{4} \mathrm{O}_{7}\right) \mathrm{C}$, 59.5 (59.6); H, 4.4 (3.8); N, 8.7 (8.0); \% Zn calcd(found) 10.1 (10.0); $\Lambda_{\mathrm{m}}, 12.58$.

$\left[\mathrm{PdL}_{2}\right] 0.25 \mathrm{H}_{2} \mathrm{O}: \%$ yield 50 (0.10 g); Color (brown); IR $\left(\mathrm{KBr}, \mathrm{cm}^{-1}\right): \nu \mathrm{OH} 3500 \mathrm{~b}, \nu \mathrm{C}=\mathrm{N}+\nu \mathrm{C}=\mathrm{C} 1656 \mathrm{~s} 1429 \mathrm{~s}$; $v \mathrm{M}-\mathrm{N} 571 \mathrm{~s} 510 \mathrm{~s}, v \mathrm{M}-\mathrm{O} 470 \mathrm{~m} 432 \mathrm{~m}$; VIS/UV $\lambda_{\max }$, (kK): 14.79, 22.37, 36.33, 45.84; ${ }^{1} \mathrm{H}$ NMR $\left(300 \mathrm{MHz}, \mathrm{CD}_{2} \mathrm{Cl}_{2}, \delta\right.$ in ppm): $8.70\left(\mathrm{~s}, 1 \mathrm{H}, \mathrm{HC}^{7^{\prime}} \mathrm{N}\right), 7.70-7.95\left(\mathrm{~m}, 3 \mathrm{H}, \mathrm{C}^{3^{\prime}}, \mathrm{C}^{4^{\prime}}\right.$, $\left.\mathrm{C}^{6^{\prime}}\right)$, Indane ring: $6.95-7.32\left(\mathrm{~m}, 3 \mathrm{H}, \mathrm{C}^{2}, \mathrm{C}^{3}, \mathrm{C}^{4}\right) ; 3.03(\mathrm{t}$, $\left.2 \mathrm{H}, \mathrm{C}^{5}\right), 2.06\left(\mathrm{q}, 2 \mathrm{H}, \mathrm{C}^{6}\right), 3.08\left(\mathrm{t}, 2 \mathrm{H}, \mathrm{C}^{7}\right)$; M.pt $\left({ }^{\circ} \mathrm{C}\right), 304-$ 306; formula mass (673.47); $\mathrm{CHN}$ Anal. calcd(found) for $\operatorname{Pd}\left(\mathrm{C}_{32} \mathrm{H}_{26.5} \mathrm{~N}_{4} \mathrm{O}_{6.25}\right) \mathrm{C}, 57.0$ (57.0); H, 4.0 (4.4); N, 8.3 (7.2); $\%$ Pd calcd (found) $15.4(15.4) ; \Lambda_{\mathrm{m}}, 6.51$.

2.3. Antiproliferative Effects in MCF-7 and HT-29 Cells. In 96-well plates, $100 \mathrm{~mL}$ of a cell suspension in culture medium at 7500 cells/mL (MCF-7) and 2500 cells/mL (HT-29) were plated into each well and incubated for three days under culture conditions. After the addition of various concentrations of the test compounds, cells were incubated for another $96 \mathrm{~h}$ (MCF-7) and $72 \mathrm{~h}$ (HT-29), respectively. The medium was then removed and the cells were fixed with $1 \%$ glutardialdehyde solution and stored under phosphatebuffered saline (PBS) at $4^{\circ} \mathrm{C}$. Cell biomass was determined by a crystal violet staining, followed by extracting of the bound dye with ethanol and a photometric measurement at $590 \mathrm{~nm}$. The test compounds were prepared fresh as stock solutions in DMF and diluted with the cell culture medium 


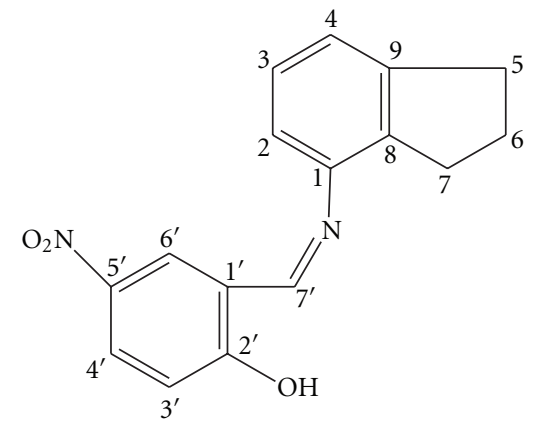

Figure 1: Proposed structure for the ligand.

TABle 1: $\mathrm{IC}_{50}$ values of the ligand and its $\mathrm{Cu}(\mathrm{II}), \mathrm{Zn}(\mathrm{II}), \mathrm{Pd}(\mathrm{II})$ complexes against MCF-7 and HT-29 cells.

\begin{tabular}{lcc}
\hline Compounds & MCF-7 $(\mu \mathrm{M})^{\mathrm{a}}$ & HT-29 $(\mu \mathrm{M})^{\mathrm{a}}$ \\
\hline $\mathrm{HL}$ & $33.3 \pm 0.0$ & $>100$ \\
{$\left[\mathrm{CuL}_{2}\right]$} & $78.0 \pm 0.1$ & $>100$ \\
{$\left[\mathrm{ZnL}_{2}\right] \mathrm{H}_{2} \mathrm{O}$} & $19.9 \pm 0.0$ & $51.6 \pm 0.0$ \\
{$\left[\mathrm{Pd}(\mathrm{L})_{2}\right] 0.25 \mathrm{H}_{2} \mathrm{O}$} & $5.9 \pm 0.0$ & $>100$ \\
\hline
\end{tabular}

${ }^{a}$ Results are expressed as means ( \pm error) of at least 2 independent experiments.

to the final assay concentrations $(0.1 \% \mathrm{~V} / \mathrm{V} \mathrm{DMF})$ and cisplatin was used as the reference drug. The $\mathrm{IC}_{50}$ value was taken as the concentration causing 50\% inhibition of cell proliferation and calculated as mean of at least two independent experiments [22].

2.4. Antimicrobial Assay. The assay was carried out on the ligand and its metal(II) complexes using Agar diffusion technique. The surface of the agar in a Petri dish was uniformly inoculated with $0.3 \mathrm{~mL}$ of 18 hours old test bacteria/fungus culture. Using a sterile cork borer, $6 \mathrm{~mm}$ wells were bored into agar. Then $0.06 \mathrm{~mL}$ of $10 \mathrm{mg} / \mathrm{mL}$ concentration of each metal complex in DMSO was introduced into the wells and the plates are allowed to stand on bench for $30 \mathrm{~min}$ before incubation at $37^{\circ} \mathrm{C}$ for $24 \mathrm{~h}$ after which inhibitory zones (in $\mathrm{mm}$ ) were taken as a measure of antibacterial activity. The experiments were conducted in duplicates and gentamycin was used as the reference drug.

\section{Results and Discussion}

The Schiff base and its complexes are obtained in good yields of $70 \%$ with the exception of $\mathrm{Pd}(\mathrm{II})$ complex with a yield of $50 \%$. All complexes isolated adopt $\left[\mathrm{ML}_{2}\right] x \mathrm{H}_{2} \mathrm{O}$ stoichiometry, with exception of the $\mathrm{Cu}$ (II) complexes which is anhydrous. Evidence for the formation of HL (Figure 1) in pure form is from microanalyses and ${ }^{1} \mathrm{H}$ NMR. The generalized equation for the formation of the complexes is

$$
\mathrm{M}\left(\mathrm{NO}_{3}\right)_{2} \cdot 2 \mathrm{H}_{2} \mathrm{O}+2 \mathrm{HL} \longrightarrow\left[\mathrm{ML}_{2}\right] x \mathrm{H}_{2} \mathrm{O}+2 \mathrm{HNO}_{3}+b \mathrm{H}_{2} \mathrm{O}
$$

(when $\mathrm{M}=\mathrm{Mn}(\mathrm{II}), x=2, b=0 ; \mathrm{Zn}(\mathrm{II}), x=1, b=1 ; \mathrm{Cu}(\mathrm{II})$, $x=0, b=2)$.
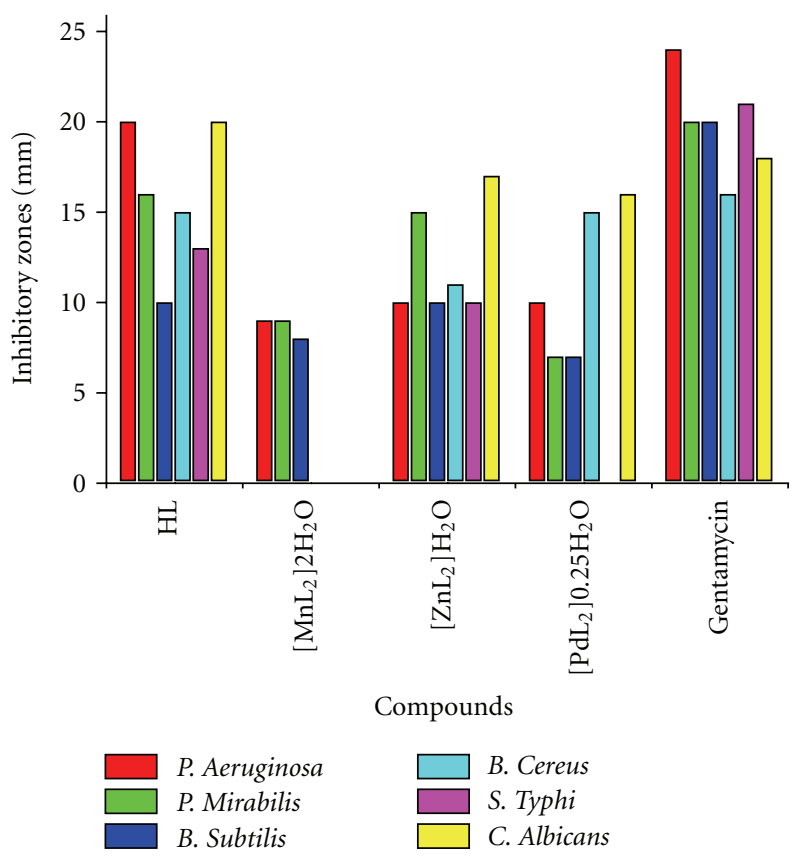

Figure 2: The comparative activities of the complexes against microbes and gentamycin.

Attempts to isolate suitable crystals for single X-ray structural determination are not successful so far.

The molar conductivities of the complexes in DMSO are in the range $1.05-30.0 \mathrm{ohm}^{-1} \mathrm{~cm}^{2} \mathrm{~mol}^{-1}$, showing that they are covalent in the solvent. A value of $94-105 \mathrm{ohm}^{-1} \mathrm{~cm}^{2}$ $\mathrm{mol}^{-1}$ is expected for a $1: 1$ electrolyte [23].

The infrared bands are assigned by comparing the spectra of the compounds with reported literature on similar systems $[5,13,14]$. The band at $3427 \mathrm{~cm}^{-1}$ in the ligand is assigned as $\nu \mathrm{OH}$ and its absence in the complexes indicates the involvement of the phenolic $O$ atom in bonding to the metal atoms. The broad band at $3500 \mathrm{~cm}^{-1}$ in the hydrated complexes is assigned to $v(\mathrm{OH})$ of crystallization water. The uncoordinated $\mathrm{C}=\mathrm{N}$ and $\mathrm{C}=\mathrm{C}$ stretching vibrations in the ligand are expectedly coupled in the range $1650-1421 \mathrm{~cm}^{-1}$ [16] and are observed in the range $1675-1404 \mathrm{~cm}^{-1}$ in the metal complexes, due to coordination via the imine $N$ atom. Further evidence of coordination is the presence of the bands due to $v(\mathrm{M}-\mathrm{O})$ and $v(\mathrm{M}-\mathrm{N})$ in the complexes at $481-410$ and $580-502 \mathrm{~cm}^{-1}$, respectively; these bands are absent in the ligand.

The spectra of Manganese(II) complexes are usually characterized by forbidden transitions from the ${ }^{6} \mathrm{~A}_{1}$ to higher quartet states for all geometries. $\left[\mathrm{MnL}_{2}\right]$ exhibits two bands at $12.0 \mathrm{kK}$ and $22.2 \mathrm{kK}$, typical of a tetrahedral geometry and are assigned to ${ }^{6} \mathrm{~A}_{1} \rightarrow{ }^{4} \mathrm{E}_{1}\left(\nu_{1}\right)$ and ${ }^{6} \mathrm{~A}_{1} \rightarrow{ }^{4} \mathrm{~A}_{1}\left(\nu_{2}\right)$ transition [24]. Regular tetrahedral Copper(II) complexes have a single broad band below $10.0 \mathrm{kK}$, while square-planar complexes usually absorb in the range $10.0-20.0 \mathrm{kK}$. The observance of two bands at $13.89 \mathrm{kK}$ and $22.52 \mathrm{kK}$ in $\left[\mathrm{CuL}_{2}\right]$ supports the assignment of the bands to ${ }^{2} \mathrm{~B}_{1 g} \rightarrow{ }^{2} \mathrm{~A}_{1 g}$ and ${ }^{2} \mathrm{~B}_{1 \mathrm{~g}} \rightarrow{ }^{2} \mathrm{E}_{1 \mathrm{~g}}$ transitions in a square planar environment 
TABLE 2: Zones of inhibition (in $\mathrm{mm}$ ) of the compounds against various microbes.

\begin{tabular}{lcccccc}
\hline Complexes & Pseudomonas aeruginosa & Proteus mirabilis & Bacillus subtilis & Bacillus cereus & Samonella typhi & Candida albicans \\
\hline $\mathrm{HL}$ & $20.0 \pm 0.1$ & $16.0 \pm 0.03$ & $10.0 \pm 0.12$ & $15.0 \pm 0.2$ & $13.0 \pm 0.1$ & $20.0 \pm 0.02$ \\
{$\left[\mathrm{MnL}_{2}\right] 2 \mathrm{H}_{2} \mathrm{C}$} & $9.0 \pm 0.1$ & $9.0 \pm 0.02$ & $8.0 \pm 0$ & $\mathrm{IA}$ & IA & IA \\
{$\left[\mathrm{ZnL}_{2}\right] \mathrm{H}_{2} \mathrm{O}$} & $10.0 \pm 0$ & $15.0 \pm 0.1$ & $10.0 \pm 0.1$ & $11.0 \pm 0.02$ & $10.0 \pm 0$ & $17.0 \pm 0.3$ \\
{$\left[\mathrm{PdL}_{2}\right] 0.25 \mathrm{H}_{2} \mathrm{O}$} & $10.0 \pm 0.01$ & $7.0 \pm 0.1$ & $7.0 \pm 0.2$ & $15.0 \pm 0.2$ & IA & $16.0 \pm 0.25$ \\
Gentamycin & $24.0 \pm 0.12$ & $20.0 \pm 0.2$ & $20.0 \pm 0.2$ & $16.0 \pm 0.3$ & $21.0 \pm 0.1$ & $18.0 \pm 0.03$ \\
\hline
\end{tabular}

Abbreviations: IA: inactive.

[6]. [ $\left.\mathrm{ZnL}_{2}\right]$ has a single band at $21.50 \mathrm{kK}$ due to $\mathrm{M} \rightarrow \mathrm{L}$ CT transitions which confirms its tetrahedral geometry [14]. The spectrum of $\left[\mathrm{PdL}_{2}\right]$ expectedly shows transitions typical of square-planar geometry at $14.79 \mathrm{kK}$ and $22.37 \mathrm{kK}$, which are assigned to ${ }^{1} \mathrm{~A}_{1 g} \rightarrow{ }^{1} \mathrm{~B}_{1 g}$ and ${ }^{1} \mathrm{~A}_{1 g} \rightarrow{ }^{1} \mathrm{E}_{2 g}$ transitions [25]. The bands in the ranges $31.71-39.29 \mathrm{kK}$ and 40.08 $46.73 \mathrm{kK}$ in the ligand and its metal complexes are assigned to $\pi \rightarrow \pi^{*}$ and CT transitions, respectively.

The phenolic proton in HL is observed at $15.0 \mathrm{ppm}$, while the imine proton is seen as a singlet at $8.78 \mathrm{ppm}$. The protons on $\mathrm{C}^{3}, \mathrm{C}^{4}$, and $\mathrm{C}^{6}$ resonate as a multiplet at $8.42-8.22 \mathrm{ppm}$. The protons at $\mathrm{C}^{5^{\prime}}, \mathrm{C}^{6^{\prime}}$, and $\mathrm{C}^{7^{\prime}}$ in indane ring are observed as a multiplet at $7.29-7.06 \mathrm{ppm}$. The $2 \mathrm{H}$ at $\mathrm{C}^{1^{\prime}}$ are seen as a triplet centered at $3.02 \mathrm{ppm}$ while those at $\mathrm{C}^{2^{\prime}}$ resonate as a quintet centered at $2.15 \mathrm{ppm}$. Finally, the $2 \mathrm{H}$ at $\mathrm{C}^{3^{\prime}}$ resonate as a triplet centered at $3.05 \mathrm{ppm}$. [ $\left.\mathrm{ZnL}_{2}\right]$ spectrum shows the absence of phenolic proton at $15.0 \mathrm{ppm}$, which confirms coordination through the phenolic $\mathrm{O}$ atom. The imine proton is seen as a singlet at $8.76 \mathrm{ppm}$. The protons at $\mathrm{C}^{3}, \mathrm{C}^{4}$, and $\mathrm{C}^{6}$ resonate as a multiplet at $8.41-8.19 \mathrm{ppm}$ and are downshifted. Similarly, those at $C^{5^{\prime}}, C^{6^{\prime}}$, and $C^{7^{\prime}}$ in indane ring also resonate as a multiplet and are downshifted to 7.00-7.14 ppm. Likewise, the $2 \mathrm{H}$ at $\mathrm{C}^{\mathrm{l}^{\prime}}$ are seen as a triplet centered at $3.00 \mathrm{ppm}$ and are downshifted. The $2 \mathrm{H}$ protons at $\mathrm{C}^{2^{\prime}}$ and $\mathrm{C}^{3^{\prime}}$ resonate as quintet and triplet centered at $2.16 \mathrm{ppm}$ and $3.06 \mathrm{ppm}$ and are upshifted, respectively. These shifts are indicative of coordination through the imine $\mathrm{N}$ atom [14]. Similarly, the spectrum of $\left[\mathrm{PdL}_{2}\right]$ shows the absence of the phenolic proton at $15.0 \mathrm{ppm}$, which confirms coordination through the phenolic $\mathrm{O}$ atom. The imine proton is seen as a singlet at $8.70 \mathrm{ppm}$. The protons at $\mathrm{C}^{3}, \mathrm{C}^{4}$, and $\mathrm{C}^{6}$, and those at $\mathrm{C}^{5^{\prime}}, \mathrm{C}^{6^{\prime}}$, and $\mathrm{C}^{7^{\prime}}$ in indane ring resonate as multiplets at 7.70-7.95 and 6.95-7.32 ppm, respectively, and are downshifted. The $2 \mathrm{H}$ at $\mathrm{C}^{1^{\prime}}$ and $\mathrm{C}^{3^{\prime}}$ are upshifted and seen as a triplet each centered at $3.03 \mathrm{ppm}$ and $3.08 \mathrm{ppm}$, respectively, while $2 \mathrm{H}$ at $\mathrm{C}^{2^{\prime}}$ are seen as a quintet at $2.06 \mathrm{ppm}$ and are downshifted. These shifts are indicative of coordination through the imine $\mathrm{N}$ atom [25].

3.1. Antiproliferative Effects. The results of the anticancer activities of selected complexes and HL are presented in Table 1. Generally, MCF-7 cells are more sensitive towards exposure to the compounds than HT-29 cells. MCF-7 cells are also sensitive to the metal free ligand with an $\mathrm{IC}_{50}$ of $33.3 \mu \mathrm{M}$ Whereas the activity of $\left[\mathrm{CuL}_{2}\right]$ and $\left[\mathrm{ZnL}_{2}\right]$ is comparable to that of the free ligand or even decreased. $\left[\mathrm{PdL}_{2}\right]$ exhibits an enhanced activity with an $\mathrm{IC}_{50}$ value of $5.9 \mu \mathrm{M}$ in MCF-7 cells, which is close to that of the established metal anticancer drug cisplatin $\left(\mathrm{IC}_{50}\right.$ value of $2.0 \mu \mathrm{M}$ in the same assay) [26]. HT-29 cells are only moderately sensitive towards $\left[\mathrm{ZnL}_{2}\right]$. The increased activity of $\left[\mathrm{PdL}_{2}\right]$ against the growth of MCF-7 cells is of interest concerning the development of selective tumor therapeutics and suggests further investigations in this area.

3.2. Antimicrobial activity. The results of antimicrobial activities are presented in Table 2 and shown in Figure 2. The ligand and the $\mathrm{Zn}$ (II) complex are active against all the organisms used, That is, S. thyphi, P. mirabilis, B. subtilis, B. cereus, $P$. aeuriginosa and $C$. albicans with inhibitory zone ranges of $10.0-20.0$ and $10.0-17.0 \mathrm{~mm}$, respectively. The $\mathrm{Pd}$ (II) complex is active against all the organisms used with the exception of $S$. thyphi with inhibitory zones range of 7.0-16.0 mm, while $\mathrm{Mn}$ (II) complex has activity against $P$. aeuriginosa, $P$. mirabilis, and $B$. subtilis with inhibitory zones of $8.0-9.0 \mathrm{~mm}$.

Furthermore, the metal(II) complexes are mostly unexpectedly less effective than the free ligand, contrary to chelation theory (which states that chelation increases antimicrobial activity, because of partial sharing of its positive charge with donor groups of the ligand and possible $\pi$-electron delocalisation which increased the lipophilic character) with exceptions of $\mathrm{Zn}$ (II) and $\mathrm{Pd}(\mathrm{II})$ complexes with same activity of $10.0 \mathrm{~mm}$ and $15.0 \mathrm{~mm}$ as the ligand against Bacillus species, respectively [27]. The lower activity of the metal complexes is attributed to lower lipophilicity of the complexes, which decreases the penetration of the complexes through the lipid membrane [28].

Gentamycin activities $(18.0-24.0 \mathrm{~mm})$ against the various isolates relative to the metal complexes $(7.0-17.0 \mathrm{~mm})$ show that the activities of the latter are much lower, with the optimum activities being about the same as gentamycin in $\mathrm{Zn}(\mathrm{II})$ and $\mathrm{Pd}(\mathrm{II})$ complexes against $C$. albicans and $B$. cereus, and three quarters the activity of gentamycin in $\mathrm{Zn}$ (II) complex against $P$. mirabilis. Moreover, the ligand and $\mathrm{Zn}$ (II) complex exhibit broad-spectrum antimicrobial activity, like gentamycin, with inhibitory zones ranges of 10.0-20.0 and $10.0-17.0 \mathrm{~mm}$. Thus, proving their usefulness as potential broad-spectrum antimicrobial agents.

\section{Conclusion}

The ligand coordinates to the $\mathrm{Mn}(\mathrm{II}), \mathrm{Cu}(\mathrm{II}), \mathrm{Zn}(\mathrm{II})$, and $\mathrm{Pd}(\mathrm{II})$ ions using the azomethine $N$ and phenol $O$ atoms. 
The assignment of a 4-coordinate, square-planar/tetrahedral geometry for the $\mathrm{Mn}(\mathrm{II}), \mathrm{Cu}(\mathrm{II}), \mathrm{Pd}(\mathrm{II})$, and $\mathrm{Zn}$ (II) complexes is corroborated by electronic spectral measurements. The in vitro biological studies show that the $\mathrm{Pd}$ (II) complex has the best anticancer activity against MCF-7 cells with an $\mathrm{IC}_{50}$ of $5.9 \mu \mathrm{M}$, which is close to the activity of cis platin. Additionally, the $\mathrm{Zn}$ (II) complex and the ligand have broadspectrum activity like gentamycin, although much smaller against $P$. aeruginosa, $P$. mirabilis, $B$. subtilis, B. cereus, $S$. typhi and $C$. albicans with inhibitory zone ranges of 10.0-20.0 and 10.0-17.0 $\mathrm{mm}$, respectively.

\section{Acknowledgments}

A. A. Osowole thanks TWAS (The Academy of Sciences for The Developing World) and DFG (Deutsche Forschungsgemeinschaft) for the award of a fellowship.

\section{References}

[1] K. Gademann, D. E. Chavez, and E. N. Jacobsen, "Highly enantioselective inverse-electron-demand hetero-Diels-Alder reactions of $\alpha, \beta$-unsaturated aldehydes," Angewandte Chemie, vol. 41, no. 16, pp. 3059-3061, 2002.

[2] Z. Li, M. Fernández, and E. N. Jacobsen, "Enantioselective ring opening of meso aziridines catalyzed by tridentate Schiff base chromium(III) complexes," Organic Letters, vol. 1, no. 10, pp. 1611-1613, 1999.

[3] R. V. Heinzelmann, H. G. Kolloff, and J. H. Hunter, "Physiologically active indanamines. II. Compounds substituted in the aromatic ring," Journal of the American Chemical Society, vol. 70, no. 4, pp. 1386-1390, 1948.

[4] M. R. Borenstein, M. A. Abou-Gharbi, and P. H. Doukas, "Synthesis of spiroimides of pharmacologic interest," Heterocycles, vol. 22, no. 11, pp. 2433-2438, 1984.

[5] N. S. R. R. M. M. Koteswara Rao and M. G. Ram Reddy, "Studies on the synthesis, characterisation and antimicrobial activity of new $\mathrm{Co}(\mathrm{II}), \mathrm{Ni}(\mathrm{II})$ and $\mathrm{Zn}$ (II) complexes of Schiff base derived from ninhydrin and glycine," Biology of Metals, vol. 3, no. 1, pp. 19-23, 1990.

[6] Z. H. Abd El-Wahab, "Complexation of 4-amino-1,3 dimethyl-2,6 pyrimidine-dione derivatives with cobalt(II) and nickel(II) ions: synthesis, spectral, thermal and antimicrobial studies," Journal of Coordination Chemistry, vol. 61, no. 11, pp. 1696-1709, 2008.

[7] C. Enrique, A. García, J. M. Salas, and G. Álvarez de Cienfuegos, "Palladium(II) complexes of Schiff bases derived from 5-amino-2,4-(1H, 3H)pyrimidinedione and its derivatives," Transition Metal Chemistry, vol. 17, no. 5, pp. 464-466, 1992.

[8] M. Gaber, H. E. Mabrouk, and S. Al-Shihry, "Complexing behaviour of naphthylidene sulfamethazine Schiff base ligand towards some metal ions," Egyptian Journal of Chemistry, vol. 44, no. 4-6, pp. 191-200, 2001.

[9] M. M. J. Vijay Kumar, L. Shankarappa, H. Shameer, E. Jayachandran, and G. M. Sreenivasa, "N-Substituted-3chloro-2-azetidinones: synthesis and characterization of novel anthelmintic agents," Research Journal of Pharmaceutical, Biological and Chemical Sciences, vol. 1, no. 2, pp. 52-58, 2010.

[10] M. G. Derebe, V. J. T. Raju, and N. Retta, "Synthesis and characterization of some metal complexes of a Schiff base derived from ninhydrin and $\alpha$, L-alanine," Bulletin of the Chemical Society of Ethiopia, vol. 16, no. 1, pp. 53-64, 2002.
[11] N. G. Kozlov and K. N. Gusak, "Cyclic $\alpha$-diketones," Russian Journal of Organic Chemistry, vol. 35, no. 3, pp. 402-414, 1999.

[12] M. Tunçel and S. Serin, "Synthesis and characterization of copper(II), nickel(II) and cobalt(II) complexes with azolinked Schiff base ligands," Synthesis and Reactivity in Inorganic, Metal-Organic and Nano-Metal Chemistry, vol. 35, no. 3, pp. 203-212, 2005.

[13] C. Na, G. Zhao, G. Liu, and B. Li, "Preparation and characterization of some Schiff bases from o-vanillin and diamines," Jilin Daxue Ziran Kexue Xuebao, vol. 2, pp. 103-107, 1988.

[14] X. Han, Z. L. You, Y. T. Xu, and X. M. Wang, "Synthesis, characterization and crystal structure of a mononuclear zinc(II) complex derived from 2-methoxy- 6-[(3-cyclohexylaminopropylimino)methyl]phenol," Journal of Chemical Crystallography, vol. 36, no. 11, pp. 743-746, 2006.

[15] J. C. Dabrowiak, Metals in Medicine, John Wiley and Sons, London, UK, 2009.

[16] S. I. Mostafa and F. A. Badria, "Synthesis, spectroscopic, and anticancerous properties of mixed ligand palladium(II) and silver(I) complexes with 4,6-diamino-5-hydroxy-2- mercaptopyrimidine and 2,2' -bipyridyl," Metal-Based Drugs, vol. 2008, Article ID 723634, 7 pages, 2008.

[17] A. A. Osowole, G. A. Kolawole, and O. E. Fagade, "Synthesis, characterization and antimicrobial properties of some $\mathrm{Ni}(\mathrm{II})$, $\mathrm{Cu}$ (II) and $\mathrm{Zn}$ (II) complexes of a tetradentate Schiff-base and adduct," International Journal of Chemistry, vol. 15, no. 4, pp. 237-246, 2005.

[18] A. A. Osowole, G. A. Kolawole, and O. E. Fagade, "Synthesis, characterization and biological studies on unsymmetrical Schiff-base complexes of nickel(II), copper(II) and zinc(II) and adducts with 2,2'-dipyridine and 1,10-phenanthroline," Journal of Coordination Chemistry, vol. 61, no. 7, pp. 10461055, 2008.

[19] A. A. Osowole, G. A. Kolawole, R. Kempe, and O. E. Fagade, "Spectroscopic, magnetic and biological studies on some metal(II) complexes of 3-(4,6-Dimethyl-2Pyrimidinylamino)1-Phenyl-2-Butenone and the Mixed complexes with 2,2' Bipyridine and 1,10-Phenanthroline," Synthesis and Reactivity in Inorganic, Metal-Organic and Nano-Metal Chemistry, vol. 39, no. 3, pp. 165-174, 2009.

[20] A. A. Osowole, R. Kempe, R. Schobert, and S. A. Balogun, "Synthesis, characterisation and in-vitro biological activities of some metal(II) complexes of 3-(-1-(4-methyl-6-chloro)2-pyrimidinylimino)methyl-2-napthol," Canadian Journal of Pure and Applied Science, vol. 4, no. 2, pp. 1169-1178, 2010.

[21] J. Bassett, R. C. Denney, G. H. Jeffery, and J. Mendham, Vogel's Textbook of Quantitative Inorganic Analysis, ELBS, London, UK, 1978.

[22] G. Rubner, K. Bensdorf, A. Wellner, S. Bergemann, I. Ott, and R. Gust, "[Cyclopenta dienyl] metal carbonyl complexes of acetylsalicylic acid as neo-anticancer agents," European Journal of Medicinal Chemistry, vol. 45, pp. 5157-5163, 2010.

[23] W. J. Geary, "The use of conductivity measurements in organic solvents for the characterisation of coordination compounds," Coordination Chemistry Reviews, vol. 7, no. 1, pp. 81-122, 1971.

[24] S. Durot, C. Policar, G. Pelosi, F. Bisceglie, T. Mallah, and J. P. Mahyt, "Structural and magnetic properties of carboxylatobridged manganese(II) complexes involving tetradentate ligands: Discrete complex and 1D polymers. Dependence of J on the nature of the carboxylato bridge," Inorganic Chemistry, vol. 42, no. 24, pp. 8072-8080, 2003.

[25] Cherayath, J. Alice, and C. P. Prabhakaran, "Palladium(II) complexes of Schiff bases derived from 5-amino-2,4- $(1 \mathrm{H}$, 
$3 \mathrm{H})$ pyrimidinedione (5-aminouracil) and 1,2-dihydro-1,5dimethyl-2-phenyl-4-amino-3H-pyrazol-3-one," Transition Metal Chemistry, vol. 15, no. 6, pp. 449-453, 1990.

[26] I. Ott, K. Schmidt, B. Kircher, P. Schumacher, T. Wiglenda, and R. Gust, "Antitumor-active cobalt-alkyne complexes derived from acetylsalicylic acid: studies on the mode of drug action," Journal of Medicinal Chemistry, vol. 48, no. 2, pp. 622-629, 2005.

[27] S. Chandra, S. Parmar, and Y. Kumar, "Synthesis, spectroscopic, and antimicrobial studies on bivalent zinc and mercury complexes of 2-formylpyridine thiosemicarbazone," Bioinorganic Chemistry and Applications, vol. 2009, Article ID 851316, 6 pages, 2009.

[28] R. Nair, A. Shah, S. Baluja, and S. Chanda, "Synthesis and antibacterial activity of some Schiff base complexes," Journal of the Serbian Chemical Society, vol. 71, no. 7, pp. 733-744, 2006. 


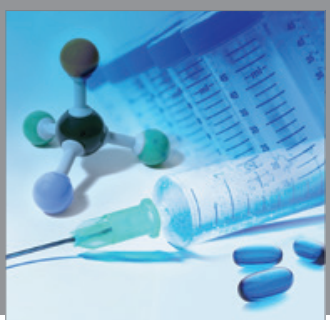

International Journal of

Medicinal Chemistry

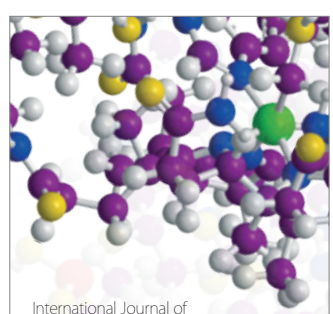

Carbohydrate Chemistry

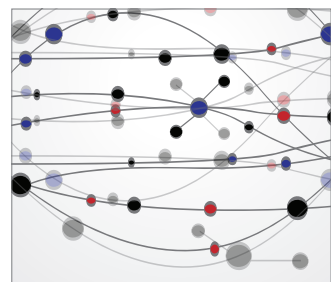

The Scientific World Journal
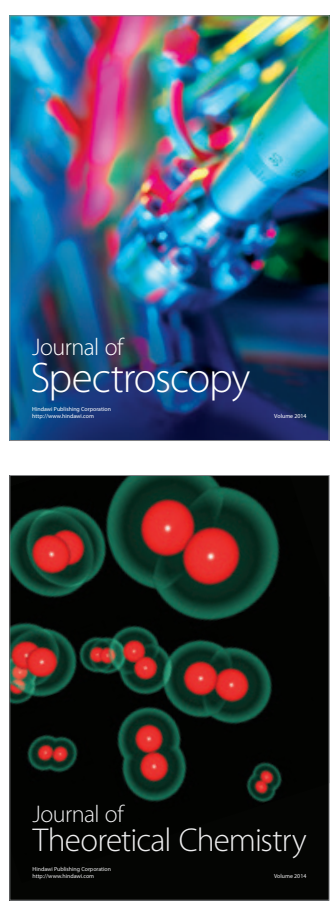
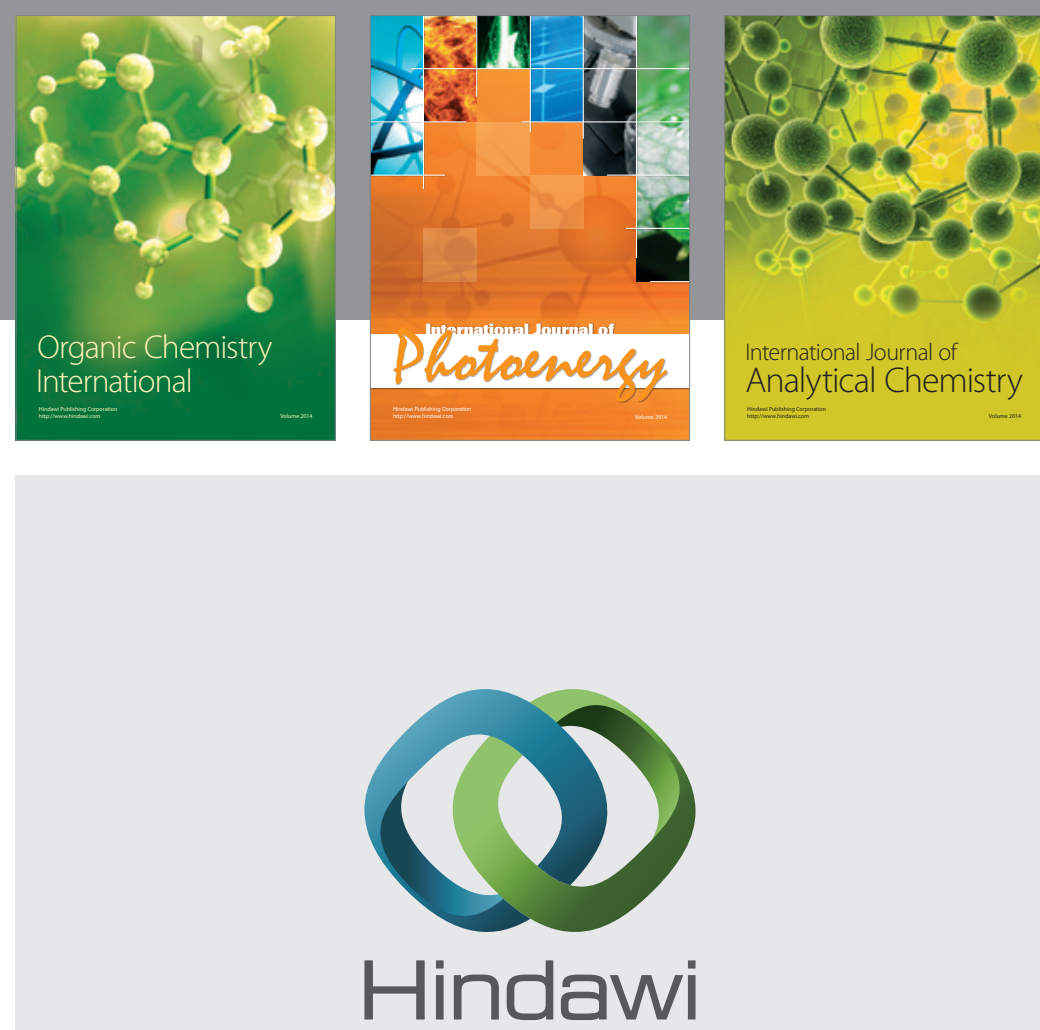

Submit your manuscripts at

http://www.hindawi.com
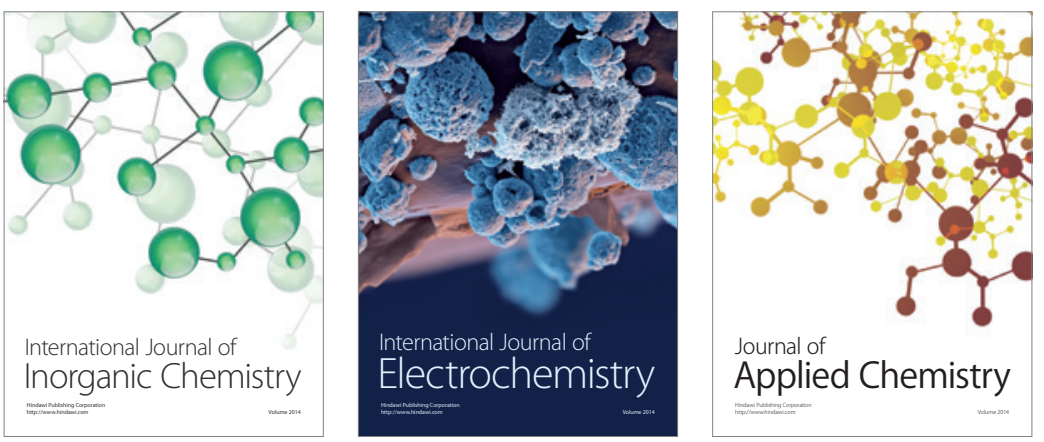

Journal of

Applied Chemistry
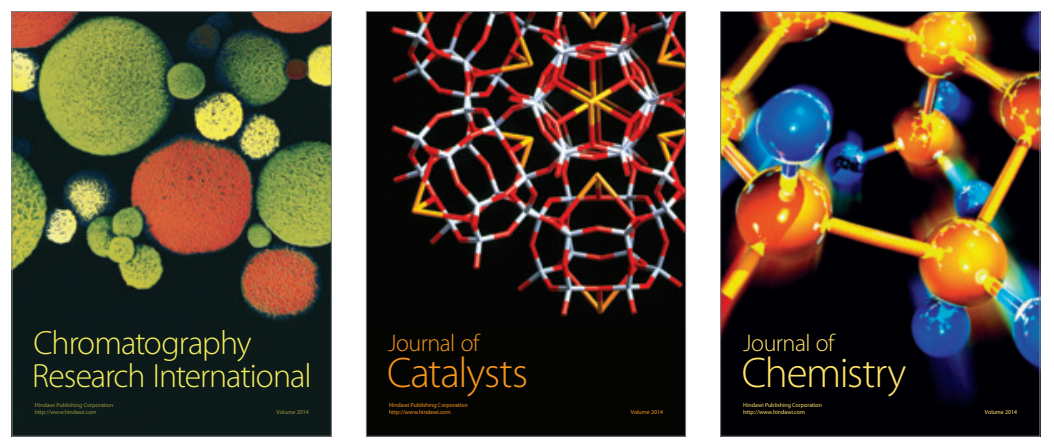
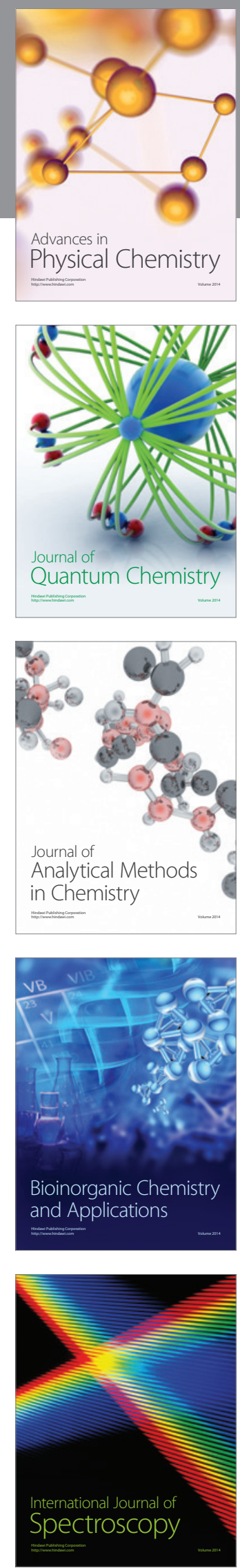